\author{
Ангелов Г.В. \\ доктор философии, профессор \\ E-mail: sociologia.kafedra@mail.ru \\ Шевченко А.А. \\ кандидат философских наук, профессор \\ кафедра социологии, срилософии и права \\ Одесская национальная академия пищевых технологий \\ ул. Канатная, 112, г. Одесса, Украина, 65039 \\ E-mail: sociologia.kafedra@mail.ru
}

\title{
ПАРАДИГМЫ СОЦИОТЕХНИЧЕСКОЙ ДЕЯТЕЛЬНОСТИ И ПОДГОТОВКА ИНЖЕНЕРНО-ЭКОНОМИЧЕСКИХ КАДРОВ В ХХІ ВЕКЕ
}

\begin{abstract}
C гуманистических позиций анализируются проблемы современных парадигм социотехнической деятельности и подготовки инженерно-экономических кадров. Установлена теоретическая и практическая возможность рационального фрормирования парадигм социотехнической деятельности и соответствующих им научных и организационных мероприятий подготовки инженерно-экономических кадров. Представлены основные тенденции формирования методов современного образования, соответствующих новейшему отечественному и иностранному опыту.
\end{abstract}

Ключевые слова: гуманизм; парадигма; социотехническая деятельность; инженерия.

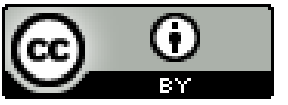

This work is licensed under a Creative Commons Attribution 4.0 International License http://creativecommons.org/licenses/by/4.0/
Постановка проблемы и ее связь с важными научными и практическими заданиями. Воздействие человека на окружающий мир (природу и социальную среду) осуществляется в соответствии с его потребностями, интересами, идеалами. Сущность и характер этого воздействия в значительной мере детерминирован способностью к свободному целеполаганию, базирующемуся на ценностно-нравственной ориентации человека, понимании им своих возможностей, целей, задач и ответственности за преобразовательную деятельность.

В этом процессе социотехническая деятельность играет лидирующую роль, так как с технической стороны имеет целью создание благоприятных условий для труда и быта людей, а с организационной - непосредственно направлена на изменение социальных отношений и моральнопсихологического климата в производственном объединении. В своей деятельности человек базируется на определенных моделях мышления и ценностного восприятия мира, усвоенных в процессе воспитания и обучения.

Эти гносеологические и социальнопсихологические установки (парадигмы) детерминируют выбор приоритетов и предпочтений в процессе социотехнической деятельности. Философское осмысление этих сущностных моментов деятельности человека выявляет имманентное содержание социотехнической деятельности, ее природу и специфику. По своему объему и смыслу понятие «парадигма» (с греч. пример, образец) достаточно изменчиво во времени. В античной и средневековой традиции термин употреблялся для характеристики взаимоотношений реального и духовного мира. В немецкой классической идеалистической философии изучение парадигм производилось на основе анализа принципов внутреннего и внешнего единства различных формообразований.

Анализ последних публикаций по проблеме. В философию науки понятие парадигмы было введено позитивистом Г.Бергманом, который характеризовал её как нормативность методологии. Однако широкое распространение этот термин получил благодаря исследованиям сущности парадигмы Т.Куном, который указывал, что под парадигмами он подразумевает «признанные всеми научные достижения, которые в течение определенного времени дают научному сообществу модель постановки проблем и их решений» [1]. Иными словами, парадигмы, являясь базисом научных традиций, представляют собой эталон научного мышления, выполняют как познавательную, так и нормативную функцию в разрешении мировоззренческих и практических задач человека. Представляя собой высший уровень организации научного знания, парадигмы наделяют исследователей и основными познавательными принципами деятельности, и формами реализации этих принципов, являясь источником методов, методик и методологии, принятых в данном социуме. 
Вопросы парадигмы социотехнической деятельности рассматриваются также в работах таких ученых как А. Азимов, В. Горохов, В. Кремень, В. Степин, М. Розов, Д. Джонс и др.

Формулирование целей исследования. Целью исследования является определение парадигм социотехнической деятельности и подготовка инженерно-экономических кадров в XXI веке.

Изложение основных результатов и их обоснование. Парадигмы культуры являются социально-психологическими установками, эталоном ценностных ориентаций технологии, социотехнической деятельности в целом. Парадигмы культуры формируют готовность субъекта технического развития и производства к осознанному выбору типа деятельности и неприятию другого. Иллюстрацией к этому может служить гигантомания и пренебрежение к удобствам человека в российской технической культуре (царь-колокол, царь-пушка, первые советские трактора без кабин и с металлическими сидениями для водителей, КАМАЗЫ, которые по комфортабельности не идут ни в какое сравнение с их зарубежными аналогами). Доминантная парадигма культуры европейской техногенной цивилизации и сегодня имманентно детерминирует качественный характер общенаучных, специализированных и локальных парадигм культуры, в том числе - и парадигм социотехнической деятельности. Социотехническая деятельность, ставящая на службу человеку могучие силы природы, неизбежно превращается в источник повышенной опасности, исходящей от технических объектов, управляемых людьми (автомобилей, станков, энергетических систем и т. п.). Возникает технологическая парадигма культуры, соответствующая степени этой опасности, культуры, предполагающей определенный уровень осмысления, понимания, предупреждения нежелательных последствий неосторожного, безответственного использования современных технологий. Иначе «чернобыли» с все более ужасающей разрушительной силой будут взрываться, пока не уничтожат человечество. Одним из непреложных условий предупреждения асоциальных последствий технического прогресса является формирование в культуре парадигмы самоценности человеческой жизни и вообще всего живого. И технология средств массового уничтожения (ядерного, водородного оружия) подводит к этой парадигме, разрушая у потенциального агрессора надежду на победу и собственное выживание даже в случае «успешного» результата в уничтожении противника. Ведь такая «победа» может означать ликвидацию условий для жизни на Земле.

Современная социотехническая деятельность порождает технологии, являющиеся универсальным средством сбережения человеческих усилий, рабочего времени, затрачиваемого на удовлетворение имеющихся потребностей, создающие резерв свободного времени, в пределах которого деятельность людей уже не подчиняется принуди- тельному трудовому ритму и может регулироваться преимущественно внутренними мотивами личности. Возникает проблема использования свободного времени, которое в условиях низкой культуры населения может обернуться бедствием: интеллектуальной и нравственной деградацией человека, неспособного управлять разумно самим собой. Однако технология подчиняет себе весь повседневный уклад культуры, духовную жизнь общества. Господство радиоэлектронных средств информации, «экранизация» труда, компьютеризация обучения и досуга нивелирует культурные особенности наций и регионов, формирует у молодежи парадигмы пассивного потребления в сфере культуры вместо самодеятельности.

В процессе формирования новой парадигмы социотехнической деятельности в таком контексте не может не учитываться следующий фактор: современное человечество осознало свою смертность, которая может быть детерминирована техническими и нравственными причинами. В ходе широкомасштабной социотехнической деятельности, детерминировавшей «торнадный» поток новых технологий, человек четко осознал две объективные истины: 1) индивид и человечество в целом представляет собой часть единого организма биосферы; 2) природа является не только и не столько неисчерпаемой кладовой и мастерской для человека, но - единственно возможной и наличествующей средой обитания человеческого рода, уже достаточно «изъязвленной» и деформированной последним.

Современный мир пребывает в состоянии глубокого кризиса, обусловленного в первую очередь духовным состоянием человечества, характеризуемым многими философами и социологами как бездушное и бездумное. Такая духовная ситуация во многом детерминирована всесторонним и массированным проникновением техники, технического способа разрешения проблем во все сферы материального и духовного производства общества, человечества в целом. В поисках путей выхода из этой ситуации видный украинский ученый В.Г.Кремень отводит образованию важную роль: «... саме освіта здатна поновити «связь времен», вказати шляхи виходу 3 духовної кризи людства. Адже саме освіта відповідальна за трансляцію культурної спадщини людства» [2].

Почему, размышляя о перспективах развития техники, мы все чаще сталкиваемся с противлением ей, с враждебностью и страхом людей за свое будущее? Ведь, преобразуя окружающий мир при помощи техники и технической деятельности, человек облегчает свою жизнь, высвобождает время для «высоких» видов деятельности, связанных с его творчеством и духовностью. Человек боится не техники. Человек боится своей сущности, которая проявляется тем ярче и рельефнее, чем он ощущает себя независимее от природы и окружающего мира. Опасность состоит не только в том, что человек может применить созданную технику двояко - в 
конструктивных и деструктивных целях. Настоящая опасность лежит глубже: в долгой синусоиде опредмечивания и распредмечивания технических решений, техники в прогрессии изменяется сущность самого человека - он начинает мыслить рецептурноконкретно, абстрагируясь от «лишних» эмоций и чувств. На практике такое мышление реализуется в отношении к себе и окружающим людям с потребительской установкой: насколько этот человек нужен мне для достижения целей (насколько этот механизм незаменим, эффективен в моей служебной либо семейной «машине»)? Опасность такого мышления лежит не только в этической плоскости, но в возможности изменения характера и сущности человеческой культуры, во все нарастающей вероятности «выпадения» определенных эмоций из ассортимента ныне еще существующих. При исчезновении эмоций такая потеря уже значительно увеличится на уровне чувств. И эта цепная реакция превращения человека в машину уже не сможет быть остановлена.

В предотвращении такого развертывания сценария человеческого бытия главенствующая роль отводится инженерии. Проблема инженерного мышления и инженерной деятельности является совокупностью «межблочных» задач философии техники, ибо не может быть отнесена в чистом виде ни к социальным, ни к антропологическим проблемам: инженер сочетает в себе качества индивида, т. е. представителя человеческого рода как биологического вида, а с другой стороны, инженер как личность обладает достаточно специфичным набором ролевых функций в обществе. Именно он непосредственно контактирует с техникой и в его деятельности неизбежно возникают дополнительные, специфичные для данного вида деятельности, психологические, нравственные, социальные проблемы. Представляя собой важный аспект человеческой деятельности и культуры, техника в своей основе является результатом рационального конструирования и рациональной деятельности. Поэтому принципиально техника поддается пониманию и управлению, существует возможность долговременной оценки последствий применения конкретного технического проекта.

В высокотехнологизированных обществах предпринимаются попытки выявления и ликвидации негативного влияния внедряемых проектов на социальные процессы, создаются правовые механизмы, регулирующие эти вопросы. Эти разработки получили название «оценки техники» или социально-гуманитарной экспертизы технических проектов. Представители Комиссии Союза немецких инженеров, занимающиеся разработкой основ оценки техники, определили в качестве центральных такие области технической деятельности, как способность функционирования, экономичность, благосостояние, здоровье, безопасность, качество окружающей среды, качество общества, развитие личности. Это иллюстрация современной парадигмы оценки технической деятельности: техника не является цен- ностно нейтральной и должна удовлетворять ряду ценностных требований. В директивах Союза немецких инженеров оценка техники определяется как «планомерное, систематическое, организованное мероприятие, которое анализирует состояние техники и возможности ее развития; оценивает непосредственные и опосредованные технические, хозяйственные, в плане здоровья, экологические, гуманные, социальные и другие следствия этой техники и возможные альтернативы» [3], т. е. является междисциплинарной проблемой, требующей подготовки специалистов широкого профиля, обладающих не только научно-техническими, но и социально-гуманитарными знаниями.

При исследовании проблем экспертизы и оценки техники неизбежно возникает вопрос о профессиональной принадлежности той группы людей, чье мнение будет оказывать решающее значение, тех ученых и практиков, которые сумеют осознать, интегрировать весь поток аксиологической информации и требований, который поступит от представителей различных наук по поводу применения данной технической инновации. Очевидно, что решающая роль здесь отводится инженерам. Но в условиях индустриального общества вся система подготовки инженеров предусматривает формирование такого специалиста, который сумеет придать дополнительный импульс индустриализации общества. Сторонники концепции «индустриального разума» считают, что в условиях индустриального общества формируется рассудочный, механический тип деятельности - как профессиональной, так и социальной - инженера, в котором превалирует бездушность и бездумность в моральном и общечеловеческом аспектах.

Однако существует более оптимистичный и, на наш взгляд, более продуктивный подход к пониманию перспектив инженерии: инженер является членом своего общества, и в его ценностях и нормах отражаются ценности и нормы данного общества, его пороки и несовершенства. И общечеловеческие этические нормы в рамках инженерной деятельности обладают дополнительной спецификой. Эта «дополнительность» представляет собой особую ответственность перед обществом за гуманистическое разрешение амбивалентности техники в каждом конкретном случае создания и применения технического устройства. Современный инженер, пользуясь техническими знаниями, навыками и средствами, преобразовывая мир на основе научного мировоззрения, в первую очередь должен быть высокоморальным гражданином, человеком с хорошо развитым не только разумом, но и душой, совестью. А потому слова знаменитого инженера П.К.Энгельмейера о том, что инженер должен «внутри собственной среды повысить умственное развитие и проникнуться на основании исторических и социологических данных всею важностью своей профессии в современном государстве» [4] представляются нам основной парадигмой современного инженерного мышления, деятельности 
и образования.

Попытки повышения эффективности в достижении творческого уровня овладения знаниями будущими инженерами предпринимаются отечественными и зарубежными педагогами уже достаточно давно. Развитие познавательных способностей студентов обеспечивает достижение трех основных уровней овладения знаниями будущими инженерами: способности идентифицировать и воспроизводить адекватный целям исследования блок информации; способности самостоятельно разрешить задачу, являющуюся типовой в отношении информации, полученной в процессе обучения; способности к творческому разрешению принципиально новых для обучаемого задач на основе информации, полученной в ходе обучения и постоянно пополняемой в процессе самообразования.

Уже с XVIII века инженерная деятельность как профессия находится в тесном единстве с применением научных знаний в технической практике. К началу XX века инженерная деятельность представляла собой сложную систему различных видов деятельности (изобразительной, конструкторской, проектировочной, технологической и т. д.), детерминировала и обслуживала функционирование разнообразных сфер техники (машиностроения, химических технологий и т. д.), что значительно повысило потребность в привлечении в производство инженерных кадров, способных к творческому, нестандартному подходу в процессе разрешения проблем, возникающих в процессе и по поводу производства.

Для инженерной деятельности в XXI веке характерна глубокая дифференциация по различным функциям и отраслям, приведшая к структурированию ее на целый ряд взаимосвязанных видов деятельности и обеспечивающих их подвидов. Сложная организация подвидов (кооперантов) инженерной деятельности имеет богатую историю. На первых этапах своего развития инженерная деятельность, ориентируясь преимущественно на применение физических и математических знаний, включала в себя изобретательство, конструирование опытного образца и разработку технологии изготовления новой технической системы. Здесь инженерная деятельность изобретателей, конструкторов и технологов тесно связана с технической деятельностью, выполняемой на производстве техниками и рабочими. Последняя становится исполнительской по отношению к инженерной деятельности, а связь между ними осуществляется с помощью чертежей, изготовляемых «учеными рисовальщиками» [3], которыми в России того времени называли чертежников.

Структура инженерной деятельности с течением времени усложнялась и на классическом этапе своего развития она включала: 1) изобретательскую деятельность (создание на основании научных знаний и технических изобретений новых принципов действия, способов их реализации в конструкции технических систем); 2) конструирование и организацию производства технических систем; 3) инженерные исследования (системы, элементами которых являются: проектное исследование, научное обоснование разработки, анализ возможности использования спектра имеющихся научных данных для инженерных расчетов, характеристика эффективности разработки, анализ необходимости проведения дополнительных научных исследований и т. д.); 4) проектирование (научно-технические расчеты на чертеже параметров будущей технической системы). Именно последний компонент классической инженерной деятельности детерминирован социальным заказом, под которым современные российские исследователи философии техники В.С.Степин, В.Г.Горохов, М.А.Розов понимают «потребность в создании определенных объектов, вызванную либо «разрывами» в практике их изготовления, либо конструкцией, либо потребностями развивающейся социальной практики».

Цель современного проектирования, выделившегося в сфере инженерной деятельности и обособившегося в самостоятельную область деятельности во второй половине XX века, уже не ограничивается разработкой чертежей конструкции, но состоит в ориентировании и организации «проектирования как

процесса, который кладет начало изменениям в искусственной среде» [5]. Проектирование как сущностное ядро социотехнической деятельности в силу своей многомерности и разноплановости многими исследователями понималось по-разному, о чем Д.Джонс пишет: «вот некоторые определения и формулировки процесса проектирования: «отыскание существенных компонентов какой-либо физической структуры» (Александер); «целенаправленная деятельность по решению задач» (Арчер); «принятие решений в условиях неопределенности с тяжелыми последствиями в случае ошибки» (Азимов); «моделирование предполагаемых действий до их осуществления, повторяемое до тех пор, пока не появится полная уверенность в конечном результате» (Букер); « определяющий фактор для тех частей изделия, которые вступают в контакт с людьми» (Фарр); «приведение изделия в соответствие с обстановкой при максимальном учете всех требований» (Грегори); «вдохновенный прыжок от фактов настоящего к возможностям будущего» (Пейдж); «творческая деятельность, которая вызывает к жизни нечто новое и полезное, чего ранее не существовало» (Ризуик) [5].

В начале XXI века проектирование понимается как процесс, закладывающий онтологические и аксиологические принципы и начала изменениям в искусственной среде, что детерминирует появление и применение новой методологии процесса, построенной на участии разнопрофильных высококвалифицированных специалистов в коллективной разработке проекта. Основные задачи социотехнической деятельности 
перемещаются из сферы разработки артефактов в область прогностического анализа тех изменений, которые детерминируют выпуск проектируемой продукции в сферах промышленного производства и сбыта, потребительский спрос и общество в целом.

Соответственно этому движению, основанному на парадигме понимания и организации социотехнической деятельности и ее продуктов в широком контексте происходящих и будущих социальных процессов, происходит развитие принципов, форм и методов образования. Последние все активнее включают технические средства обучения, моделирование, разрешение проблемных ситуаций, деловые игры и другие методы активизации познавательной деятельности обучающихся с целью развития творческого уровня мышления, способности принимать нестандартные решения и чувства ответственности за кратко- и долговременные последствия принятого технического решения. Появление и развитие этих методов обучения отражают процессы, имевшие место в социотехнической деятельности: переход от кустарных промыслов с традиционной передачей знаний, умений и навыков, в которых проектирование базировалось на эмпирическом методе проб и ошибок к «экспериментированию» на чертежах, представляющих собой «масштабные зрительные модели изделий и средства передачи основных конструктивных данных от разработчиков к изготовителям и последующим разработчикам» [5].

Во второй половине XX века выделение из сферы инженерной деятельности и обособление проектирования в самостоятельную область деятельности детерминировало создание кризисной ситуации традиционного инженерного мышления, «ориентированного на приложение знаний лишь естественных и технических наук и созданию относительно простых механических систем» [3], результатом чего стало формирование социотехнической деятельности, ориентированной на создание сложных технических систем. Здесь изменяется не только объект инженерной деятельности (вместо отдельного технического устройства, механизма, машины и т. д. объектом исследования и проектирования становится сложная система «человек-машина»), но трансформируется и сам характер инженерной деятельности, в которой наряду с дифференциацией по отраслям и видам нарастают интеграционные процессы, организацию и руководство которыми призваны обеспечить качественно новые специалисты - инженерысистемотехники.

Системотехническая разрабатывающих подсистемы проекта работ которых координируется и управляется специальной группой специалистов-универсалов, называющихся инженерами-системотехниками. Очевидно, что в такой ситуации проектирование не является исключительно плодом технических наук, т. к. инженерная деятельность расширила границы всех разработок и вышла в социально-техническую и социально-экономическую сферы, что детерминировало обособление проектирования в самостоятельную область деятельности и преобразование его в системное проектирование. Специфической особенностью последнего является направленность не только на разработку машинных компонентов, но и ориентация на проектирование или усовершенствование человеческой реальности. Это приводит к ситуации кардинального изменения связей между инженерной деятельностью и инженерным проектированием - последнее входило неотъемлемым компонентом в традиционную инженерную деятельность. Системное же проектирование, наоборот, может включать (в случае создания новых машинных компонентов) инженерную деятельность, а может и нет, т. к. сфера его приложения совпадает со всеми областями социальной практики, в которой промышленное производство - лишь подсистема наряду со сферами, свободными от инженерной деятельности, например, обучения, управления и т. д. Такая ситуация детерминирует необходимость формирования специалистов качественно иного уровня, синтезирующих глубокие знания не только технических и естественных, но и наук социально-гуманитарного профиля, наделяющих подлинно философским мировоззрением, глубоким пониманием сущности и характера общечеловеческих ценностей, необходимости интеграции последних с национальными ценностями в процессе проектирования и производства новых технологий и техники.

Вершиной развития системотехнического проектирования становится формирование социотехнического проектирования, глобальной задачей которого является активное, целенаправленное преобразование социальноорганизационных структур. Здесь фокус проектирования лежит не в сфере создания машинных компонент, но в области человеческой деятельности, ее социальных и психологических аспектов. Специфика современного социотехнического проектирования заключена в двух взаимопересекающихся и взаимно детерминируемых плоскостях: с одной стороны, социотехническое проектирование характеризуется гуманитаризацией. Как подчеркивают российские философы В.С.Степин и другие, «проектирование само становится источником формирования проектной тематики и вступает тем самым в сферу культурно-исторической деятельности», т. е. объектом проектирования является сама область проектной деятельности, в которой формируется «особый методический слой, направленный на выработку норм и предписаний для проектных процедур, и теоретический слой, обеспечивающий методистов знаниями об этих процедурах» [3].

Иными словами, саморазвивающаяся система проектной деятельности имеет своим механизмом саморазвития противоречия между возможностями подлинно гуманистической 
проектной деятельности и системой имеющихся знаний, на которых базируется проектная деятельность. В процессе развития этой системы происходит дальнейшее движение знаний о проектировании и для него в контексте усовершенствования гуманистической направленности норм этой деятельности.

С другой стороны, социотехническое проектирование является проектированием без протоколов, в него вовлечены различные типы деятельности, в ходе которых воплощаются идеалы, сформированные в культуре. Таким образом, в тесном взаимодействии с такими культурными феноменами, как управление, прогнозирование, организационная деятельность и др., социотехническое проектирование, модифицируясь, трансформирует культуру.

Социотехническое проектирование имеет качественно иной характер по сравнению с традиционной инженерной и системотехнической деятельностью. Последнюю роднит с социотехнической деятельностью направленность на проектирование систем типа «человек-машина», однако социотехническое проектирование выходит за границы традиционной триады «наука-инженерияпроизводство» в область разнообразных видов социальной практики, т. е. становится самостоятельной сферой современной культуры. Социотехническая парадигма проектирования в XXI веке детерминирует все области инженерной деятельности и всю техносферу, что обусловливает четкое понимание необходимости экологической, социальной и т. д. оценки техники, сознание социальной ответственности инженера и проектировщика.

Известно, что выполнение любых профессиональных задач - будь то производственные, торговые, управленческие и пр., - требуют от человека определенных нравственно-этических качеств, поступков и включения его в определенные нравственные отношения. Это обусловлено тем, что любой вид специализированной деятельности имеет свои неповторимые ситуации, трудности и противоречия, которые необходимо разрешать и преодолевать в ходе самой деятельности, что порождает в любой деятельности ее этико-моральную специфику. Последнее налагает обязанность изучать, исследовать эту специфику, обучать персонал, т. е. способствовать овладению этой профессиональной спецификой всеми работниками данного вида деятельности. Это означает необходимость наладить постоянно действующий учебно-педагогический процесс.

Педагогический процесс по внедрению в сознание рыночников основ этики поведения особо важное значение приобретает в менеджерской руководительской практике. В менеджменте роль этико-морального фактора особенно велика потому, что здесь сама мораль выполняет педагогическую функцию: менеджер - это руководитель-воспитатель, наставник и контролер, который формирует произ - водственное лицо и, следовательно, нравственный облик подчиненных ему исполнителей. А педагогический эффект такого дела в большой мере зависит от типа формирующей личности. Воспитатель прежде всего сам должен быть воспитан. Собственное поведение воспитателя-наставника ни в коем случае не должно расходиться с предписаниями морали. Значит, в первую очередь педагогический процесс касается обучения самих наставников. Наставник по своему нравственному развитию должен стать выше среднего уровня.

В обучении руководителей нравственные отношения рекомендуется рассматривать в двух аспектах: в аспекте нравственного сознания, т. е. тех требований, которые предъявляются к самому руководителю в процессе выполнения им своих обязанностей, и в аспекте реального поведения людей - их мотивов, поступков, следствий с целью перехода от нравственных принципов к нравственной практике с тем, чтобы возможно стало управлять исполнителем незаметно для него (взрослые не терпят, когда их открыто «воспитывают»). Содержание обучения по первому аспекту - внедрение в сознание менеджера его профессиональных обязанностей - сводится, если говорить в сокращенном варианте, к так называемому «профессиональному кодексу менеджера» - пособию весьма распространенному в нынешнем рыночном мире. Содержательная квинтэссенция подобных кодексов представляется следующей:

- в составе производственной общины относиться ко всем другим профессиям так же, как он (менеджер) хотел бы, чтобы относились к нему;

- стоять на стороне исполнителя или коллеги, который действовал от его имени или по его просьбе;

- беседовать конструктивно с коллегами и давать им только объективную информацию;

- активно участвовать в профессиональных организациях и стараться достичь цели, к которой стремятся эти группы;

- совершенствовать свое профессиональное мастерство путем занятий, участия в совещаниях и посещения профессиональных собраний.

Таким образом, разрабатываемые профессионально-этические кодексы направлены не только на развитие подготовленности менеджеров, но и на унификацию их действий и поведения. Это обеспечивает единогласие, единодушие и единство педагогического воздействия на подчиненных, что исключает конфликтность на производстве и угрозу снижения прибылей. Профессионально-этические кодексы регулируют нормы поведения руководителяменеджера, нормы, которые направлены на консолидацию рабочих коллективов и на профессиональное и духовное формирование «надежного оператора» в труде. Все это осуществляется через педагогический процесс.

Поскольку педагогический труд, взятый в единстве всех своих компонентов, является особой сферой общественной жизни, обладающей относительной самостоятельностью по отношению к 
другим видам деятельности и составляет особую общественную функцию, то целесообразно рассмотреть педагогический труд как специализированный процесс.

Основной особенностью педагогического труда (везде - в вузе, на производстве и пр.) является его большая социальная ответственность, сложная структура и динамичность, особо сложная форма сотрудничества с обучаемыми и воспитываемыми и большой ролью субъективного фактора (авторитетности личности обучающего). О большой социальной ответственности педагогического труда много распространяться не приходится: он направлен на профессиональное, нравственное, моральное, этическое и политическое преобразование личности человека - и в этом ответственность такого труда перед обществом. При этом надо учесть, что педагогическое воздействие на людей протекает не гладко - объект воздействия в процессе «обработки» оказывает определенное сопротивление, которое хотя и сродни сопротивлению любого материала, но значительно превосходит его богатством форм и сложностью проявлений. Именно в этой связи известный украинский педагог А.С.Макаренко резонно возмущался: «Почему в технических вузах мы изучаем сопротивление материалов, но не изучаем сопротивление личности, когда еe начинают воспитывать» [6]. Чтобы оправдать социальную ответственность, субъекту обучения надо суметь активизировать объект обучения, так как педагогическое воздействие возможно лишь как воздействие двустороннее: когда активно действует не только обучающий, но и обучаемый.

Другая особенность педагогического труда сложность и динамичность его структуры выявляется в том, что в ходе педагогической работы, т. е. выполнения обучающим своей функции, исполнитель и инструмент как бы сливаются воедино, как при игре на музыкальном инструменте, ибо эффект обучающего воздействия зависит от слившихся воедино динамичной способности мыслить, нравственного облика, воли и чувств воздействующего. В этом как раз и проявляется талант или бесталанность человека, взявшегося за обучение других. Следующей трудностью работы по обучению, особенно это относится к промышленнопроизводственным условиям, является то, что обучающий имеет дело не с одним обучаемым, а целой группой, а в группе, как правило, собираются люди, не одинаковые по своей общеобразовательной, квалификационной подготовленности, разные по темпераменту и жизненным позициям, по отношению к данному производству или фирме, поэтому процесс обучения осложняется проблемой налаживания сотрудничества, вовлекает в себя и процесс организации слаженного, учебного коллектива.

Наконец, успех обучающей деятельности, педагогики в целом, зависит от субъективного фактора: от личной авторитетности преподающего.

Авторитет завоевывается, как правило, высоким профессионализмом, умелым организаторс- твом и умением привлекать к себе людей. Поэтому подбирать контингент обучающих надо с учетом их всесторонней авторитетности: и деловой, и моральной, и даже семейно-личностной. А это представляет собой главную трудность при организации обучающего процесса в условиях рыночного хозяйства: в отличие от христианской и коммунистической морали в рыночном быту сняты многие моральные нормы, особенно в поведении зажиточного слоя.

Сознание личности не механически отражает и копирует общественные отношения, но, участвуя в общественных связях и отношениях, познавая мир, индивид устанавливает к различным его сторонам м аспектам свое собственное определенное отношение (положительное или отрицательное). Это субъективно-оценочное отношение личности к явлениям, событиям и людям, с которыми она прямо или косвенно взаимодействует, формирует типические черты, которые в совокупности характеризуют социальный облик личности, формируют психический склад личности. Таким образом, социально-психологический портрет личности складывается под влиянием общественных отношений и обстоятельств, в которых человек живет. И если человек видит в реальной жизни уродливые этико-психологические явления, то проповедь официальной морали воспринимается им критически, он преломляет впечатления сообразно сложившегося в его личности мироощущения и восприятия быта, реальной обстановки жизнедеятельности.

В обобщенном виде различают следующие виды социальных микросред: производственнотрудовая, общественно-политическая, учебновоспитательная, семейно-бытовая и принудительновоспитательная. Таким образом, существует столько видов социальных микросред, сколько существует видов социальной деятельности. Поэтому если данное выше обобщенное разделение микросред детализировать, то можно говорить о следующих наиболее важных видах микросред:

a) микросреда в сфере материального производства (первичные производственно-трудовые коллективы и аналогичные им сообщества);

б) микросреда в сфере эстетической деятельности (профессионально-сценическая деятельность - артисты, вокалисты, музыканты, хореографы и т. д.);

в) микросреда в сфере религиозной деятельности (первичные организации религиозных сект, христианские, мусульманские, иудаистские общины и др.);

г) микросреда в сфере научной деятельности (научные работники, преподаватели вузов);

д) микросреда в сфере образования (учителя школ, техникумов, училищ, учеников с шестилетнего возраста до совершеннолетия);

е) семья как специфическая социальная микросреда, которая первой начинает воздействовать на новорожденного; 
ж)

принудительно-воспитательная микросреда в виде пенитенциарных заведений, цель которых - временная изоляция преступников и других лиц, совершивших антисоциальные проступки, чтобы путем строгой дисциплины и принудительного труда оказывать на них положительное воспитательное действие.

Во всех перечисленных микросредах растут и воспитываются дети, которые еще на стихийнобезотчетном уровне усваивают элементы социального сознания и эталоны поведения своих родителей и старших. Так формируется идеальное сознание личности со всеми его социально-психологическими характеристиками и социально-средовыми особенностями. Формируется путем интеориоризации всего увиденного и услышанного.

Западная воспитательная система делает главным объектом изучения микросреду. Все-таки в основном социальная микросреда определяет тип личности, ее характер, качественную определенность и поведенческую направленность. Но в целом эффект этико-экономического воспитания рынка, а отсюда и дифференциация в типологии рыночников поставлена в зависимость от охвата всех уровней воспитательных воздействий, определяющих формирование субъекта рыночных отношений. Таких уровней (их называют «уровни социальной детерминации») существует три.

Первый - это социальная детерминация на уровне общества как целостной системы. На этом уровне общественное бытие детерминирует нравственное сознание общества, а последнее детерминирует практическую деятельность людей. Второй уровень детерминации - это детерминированность деятельности больших социально-экономических групп в обществе (фирм, предприятий, производственных объединений). Третий уровень детерминации - это личностный уровень, т. е. социальная детерминация сознания и поведения отдельных личностей, составляющих экономическую общность. На этом уровне мы выявляем как объективную, так и субъективную детерминированность деятельности работников. Это будет показателем успеха этико-экономического воспитания в целом.

Очевидно, что ведение этико-экономической воспитательной работы на уровне микросреды изолированно от других сред и от всего общества в целом, не приносит пользы. Но общество при этом должно быть стабильным - демократическим или автократическим, но только не охлократическим. Из сказанного видно, что этическая перестройка рыночной экономики необходима безальтернативно. Предпринимателям, ставшим на путь рыночных отношений, предстоит пройти и путь нравственноэтического самоопределения, а помощь в этом процессе им должны оказать науки социальнопсихологического цикла. Именно к этой помощи гуманитариев взывает сейчас мировая рыночная элита.

Сердцевиной процесса этического воспитания менеджера, бизнесмена является форми- рование социально-приемлемой жизненной позиции, способа приложения своих способностей. Если человек определил свое место и способ приложения сил, и при этом его деловая активность не идет вразрез с этическими требованиями общества (является социально поощряемой и отвечает экспектативным ожиданиям людей), то адепту рыночной системы обеспечены успех и удача в делах. И, напротив, когда жизненная позиция «рыночника» определена неверно, оказывается социально порицаемой, поведение человека будет характеризоваться неустойчивостью, так как встретит не только противодействие в деловых кругах, но и социально-экономический остракизм.

Комплексный подход к пониманию и рациональному преобразованию социотехнической деятельности и подготовки кадров в направлении истинной гуманизации этих процессов требует и использования комплексного подхода к методам и средствам обучения будущих инженеров и менеджеров. Не исключая использования в процессе обучения тех средств обучения, которые оправдывают себя в отечественной практике, средства обучения нового поколения дополняют существующие, придают им новые возможности использования в учебном процессе благодаря расширению функций. Средства обучения нового поколения, объединенные в комплексы для обеспечения различных уровней учебной деятельности и применения в учебных заведениях различных уровней, используя новые информационные технологии обучения, обеспечивают субъектов обучения навыками пользователя новыми информационными технологиями для использования этих средств в учебной и будущей профессиональной деятельности. Формируя учебную среду для осуществления продуктивной учебной деятельности, отвечая современным психолого-педагогическим, санитарногигиеническим и эргономическим требованиям, средства обучения нового поколения благодаря своей универсальности обеспечивают усиление межпредметных связей, активизируют учебнопознавательную деятельность объектов обучения и развивают их самостоятельность.

Выводы и перспективы дальнейших исследований. Анализ передового зарубежного опыта позволяет сформировать следующие основные тенденции создания средств обучения нового поколения:

- путем увеличения количества учебных предметов, в которых используются средства обучения, расширяется сфера использования средств обучения в учебном процессе;

$$
\text { - осуществляется }
$$

переход от

эпизодического к системному использованию средств обучения нового поколения;

повышается степень интеллектуализации средств обучения нового поколения с целью расширения сферы диалогизации учебного процесса;

- появляются средства обучения на базе информационных технологий - тренировочные 
программы, интеллектуальные наставники, системы со смешанной инициативой диалога, системы мультимедиа, экспертные системы, системы дистанционного обучения и т. д.;

- внедряется использование средств обучения нового поколения во внеучебной работе, приближая учебную деятельность к исследовательской, конструкторской и профессиональной (деловые игры, моделирование ситуаций и т. д.);

- средства обучения нового поколения активно формируют учебную среду, отвечают требованиям учебного дизайна и уплотняют учебный час путем разгрузки учебников и отказа от приоритета вербального подхода к подаче учебного материала;

- за счет многофункциональности средства
обучения нового поколения обеспечивают
индивидуальную, индивидуально-групповую и
групповую продуктивную учебную деятельность и ее
альтернативность на уровне формирования нового
стиля мышления по поводу целей деятельности и
усвоения знаний на уровне использования [7].

\title{
Література
}

1. Кун Т. Структура научных революций / Т. Кун; пер. с англ. И.З Налетова. - М.: АСТ, 1977. - 605 с.

2. Кремень В.Г. Національна освіта як культурне явище / В.Г.Кремень // Учитель. - 1999. - № 11-12. C. 14

3. Степин В.С. Философия науки и техники [Электронный ресурс] / Степин В.С., Горохов В.Г., Розов M.A. - Режим доступа: http://www.gumer.info/bibliotek_Buks/Science/Step/

4. Энгельмейер П.К. Задачи философии техники / П.К. Энгельмейер // Бюллетень политического общества. - 1913. - № 2. - С. 113

5. Джонс Д. Инженерное и художественное конструирование / Д. Джонс; пер. с англ. - М.: Мир, 1976. $377 \mathrm{c}$.

6. Макаренко А.С. Сочинения в 7 т. / А.С. Макаренко. - М.: Педагогика, 1983-1986. - Т. 1. - С. 559

7. Гуртий А.М. Средства обучения / Гуртий А.М., Жук Ю.А., Волжский В.П. - К., 1997. - С. 16-17.

Статья поступила 21.06.2016

Статья принята в печать 5.07.2016 Доступно в сети Internet 30.09.2016

\author{
Ангєлов Г.В. \\ доктор фрілософії, професор \\ E-mail: sociologia.kafedra@mail.ru \\ Шевченко А.А. \\ кандидат фрілософських наук, професор \\ кафедра соціології, фрілософії і права \\ Одеська національна академія харчових технологій \\ вул. Канатна, 112, м. Одеса, Україна, 65039 \\ E-mail: sociologia.kafedra@mail.ru
}

\section{ПАРАДИГМИ СОЦІОТЕХНІЧНОЇ ДІЯЛЬНОСТІ ТА ПІДГОТОВКА ІНЖЕНЕРНО-ЕКОНОМІЧНИХ КАДРІВ В XXІ СТОЛІТТІ}

3 гуманістичних позицій аналізуються проблеми сучасних парадигм соціотехнічної діяльності та підготовки інженерно-економічних кадрів. В статті показано, що соціотехнічна діяльність відіграє лідируючу роль, так як з технічного боку має на меті створення сприятливих умов для праці та побуту людей, а з організаційною - безпосередньо спрямована на зміну соціальних відносин і моральнопсихологічного клімату у виробничому об'єднанні. У своїй діяльності людина базується на певних моделях мислення і ціннісного сприйняття світу, засвоєних у процесі виховання і навчання. Проведений аналіз публікацій з проблеми парадигм соціотехнічної діяльності. Встановлено теоретичну та практичну можливість раціонального фрормування парадигм соціотехнічної діяльності та відповідних до них наукових та організаційних засад для підготовки інженерно-економічних кадрів. Наведено основні тенденції формування засобів сучасного навчання згідно з новітнім вітчизняним та іноземним досвідом. покоління.

Авторами зроблена спроба визначення основних тенденцій створення засобів навчання нового

Ключові слова: гуманізм; парадигма; соціотехнічна діяльність; інженерія. 


\author{
Angelov G. \\ Doctor of Philosophy, Professor \\ E-mail: sociologia.kafedra@mail.ru \\ Shevchenko G. \\ PhD, Professor \\ Department of the Sociology, Philosophy and Law \\ Odessa National Academy of Food Technologies \\ Kanatna Str., 112, Odessa, Ukraine, 65039 \\ E-mail: sociologia.kafedra@mail.ru
}

\title{
PARADIGMS OF SOCIO-TECHNICAL ACTIVITIES AND PREPARATION OF THE ENGINEERING AND ECONOMIC PERSONNEL IN THE XXI CENTURY
}

From humanistic line items problems of modern paradigms of socio-technical activities and preparation of an engineering and economic personnel are analyzed. It is shown that socio-technical activities play a leading role as from technical aspect aims at creating favorable conditions for work and life of people, and from organizational - it is directly directed to change of the social relations and moral and psychological climate in production association. In the activities the person is based on the certain models of thinking and valuable perception of the world acquired in the course of education and training. In article the analysis of publications on a problem of paradigms of socio-technical activities is carried out. The theoretical and practical possibility of rational forming of paradigms of socio-technical activities and the scientific and organizational actions of preparation of an engineering and economic personnel corresponding to them is established. The main tendencies of forming of the methods of modern education corresponding to the latest domestic and foreign experience are provided.

Keywords: humanity, paradigm, socio-technical activities, engineering.

\section{References}

1. Kun, T. (1977). Struktura nauchnokh revoliutsyi. M.: AST.

2. Kremen, V. H. (1999). Natsionalna osvita yak kulturne yavyshche. Uchytel, 11-12, 14.

3. Stepyn, V. S., Horokhov, V. H., \& Rozov, M. A. (2013). Fylosofyia nauky y tekhnyky. Retrieved 2016, from http://www.gumer.info/bibliotek_Buks/Science/Step/

4. Эnhelmeier, P. K. (1913). Zadachy fylosofyy tekhnyky. Biulleten Polytycheskoho Obshchestva, 2, 113.

5. Dzhons, D. (1976). Ynzhenernoe y khudozhestvennoe konstruyrovanye. M.: Myr.

6. Makarenko, A. S. (1983-1986). Sochynenyia v 7 t. (Vol. 1). M.: Pedahohyka.

7. Hurtyi, A. M., Zhuk, I. A., \& Volzhskyi, V. P. (1997). Sredstva obuchenyia. K. 